DOI 10.4467/2543733XSSB.21.021.13814

PIOTR OBACZ

Uniwersytet Jagielloński

\title{
Dzień ostatni, dzień pierwszy. Artykuł w piętnastolecie książki prof. Pawła Śpiewaka pt. Pamięć po komunizmie
}

Nieprzypadkowe jest przywołanie w tym miejscu tytułu filmowego cyklu z połowy lat 60. Dzień ostatni, dzień pierwszy przedstawia historie trudnego czasu przejścia od dramatu wojny i okupacji, dehumanizacji i beznadziei do niepewności dni powojennych, rzeczywistości naznaczonej pamięcią o niedawnych tragediach i egzystencjalno-moralną szamotaniną. Ludzkie doświadczenia, będące esencją historii, w doprawdy przedziwny sposób tworzą nierzadko powtarzające się schematy przeżywania. Stąd właśnie skojarzenie książki Pawła Śpiewaka z filmami w reżyserii Stanisława Różewicza, małżeństwa Ewy i Czesława Petelskich i innych, bowiem Pamięć po komunizmie również przedstawia obraz walki o nowy czas, o nowy ład, o nowe trwanie; proces przetrawiania tego, co było, i pracy nad tym, co być może lub być powinno; domykania jednego okresu i otwierania kolejnego; buksowania w błocie teraźniejszości i głośnego spierania się o przyszłość; budowania nowej narodowej i społecznej tożsamości politycznej, która zaważy na latach, które mają nadejść.

Pamięć po komunizmie ukazała się w 2005 roku, nakładem gdańskiego wydawnictwa Słowo/obraz terytoria. Książka prof. Pawła Śpiewaka nie wzbudziła szczególnej dyskusji, na którą zasługiwała (i zasługuje dalej), co jedynie potwierdziło kondycję polskiej debaty publicznej, debaty intelektualnej, i naszych skłonności zarówno do dyskusji o rzeczach trudnych, jak i do dyskusji nad pracami innych badaczy (nie wspominając o tym, że nie tak znowu często czytamy „siebie nawzajem”). Jest to opracowanie z pogranicza dyscyplin: historii, socjologii, politologii, filozofii politycznej oraz analizy dyskursu. Jak wiele prac Pawła Śpiewaka, także Pamięć po komunizmie to tekst mocny, krytyczny, przykład radykalnej analizy rzeczywistości społeczno-politycznej, a zarazem pokaz głębokiej refleksji filozoficznej i moralnej. Autor przedstawia meandry budowania polskiej demokracji po 1989 roku, przy czym jest to przedstawienie wykraczające daleko poza suchy opis, zawierające solidną naukową interpretację, a jednocześnie nieskażone ekspresją politycznego stanowiska, co bywa udziałem nazbyt wielu naukowców-komentatorów polskiej rzeczywistości społeczno-politycznej. Jest to książka, która „daje do myślenia”, w pełnym sensie tego stwierdzenia. 
Pamięć po komunizmie to książka o polskich zmaganiach związanych z budową ładu politycznego, negocjacją norm, standardów i wartości, jakie winny mu towarzyszyć, a także z tworzeniem ładu moralnego po doświadczeniach totalitaryzmu, przemocy, znijaczenia, braku suwerenności i wolności. To jednak nie wszystko, bowiem jest to praca $\mathrm{z}$ gatunku tych, które pozwalają zrozumieć teraźniejszość poprzez krytyczną analizę i interpretację tego, co ją poprzedziło. A poprzedziły ją napięcia, tarcia i konflikt między elitami oraz związanymi z nimi środowiskami intelektualnymi i społeczno-politycznymi, które doprowadziły Polskę do przełomu 1989 roku, by następnie nadawać kierunki zmianom w okresie tranzycyjnym i przewodzić przekształceniom systemowym, a w dalszej kolejności - zaważyć na kształcie rzeczywistości politycznej w Polsce. Te elity, środowiska, liderzy polityczni, intelektualni przewodnicy, ale także spory i konflikty - bodaj nigdy niewyczerpane, funkcjonują i dziś, stanowiąc trwałe elementy polskiego pejzażu politycznego; więcej nawet - w dalszym ciągu są swoistymi mechanizmami, nadającymi życiu społeczno-politycznemu w Polsce szczególną dynamikę.

Polska jest krajem postkomunistycznym, nie ma co do tego wątpliwości, to po prostu fakt historyczny. Mylne i nieprawdziwe byłoby twierdzenie, że obecna Polska - ta w 2020 roku - jest już wolna od przeszłości, tej naprawdę dawnej, i tej znacznie bliższej. Historia państwa, społeczeństwa, narodu to proces, długi i złożony proces unieważniania, odtwarzania i tworzenia - postaw, norm, struktur, wartości. I zmiana systemowa po 1989 roku, której częścią jedynie były zmiany ustrojowe, objęła całość życia społecznego we wszystkich możliwych wymiarach - stąd byłoby błędem sądzić, że obecny układ społeczno-polityczny wziął się znikąd, albo że jest rezultatem pojedynczych wydarzeń czy wybranych zjawisk politycznych, ekonomicznych, społecznych z ostatnich kilku, kilkunastu lat. Należy patrzeć dalej i szukać głębiej. Pamięć po komunizmie to przykład takiej perspektywy i ważne źródło wiedzy tak o przeszłości, jak i teraźniejszości.

Warto zatem sięgnąć po omawianą książkę Pawła Śpiewaka. Po piętnastu latach nic nie straciła na swej aktualności, zwłaszcza że obecny układ społeczno-politycznych relacji, konglomerat podmiotów polityki, stan debaty publicznej, struktura sporów aksjo-normatywnych są pochodną tego, o czym pisze warszawski uczony. Przeszłość, teraźniejszość i przyszłość są ze sobą splecione; pierwszy dzień nowego nigdy nie unieważnia tego, co jeszcze wczoraj miało swój dzień ostatni. Polska przestrzeń społeczno-polityczna jest tego znamiennym, choć jednym z niezliczenie wielu, przykładem.

Piotr Obacz, dr, politolog, teoretyk polityki, członek Polskiego Towarzystwa Nauk Politycznych oraz International Political Science Association (Research Commitee 16: Socio-Politcal Pluralism, Research Commitee 33: The Study of Political Science as a Discipline); autor licznych opracowań naukowych i dydaktycznych oraz tekstów popularnonaukowych i komentarzy publicystycznych; w 2019 roku otrzymał główną nagrodę im. Prof. Jana Baszkiewicza w konkursie na najlepszą monografię politologiczną, a w 2018 roku został wyróżniony w konkursie im. Prof. Czesława Mojsiewicza na najlepszą rozprawę doktorską; zawodowo związany z Uniwersytetem Jagiellońskim i Akademią WSB w Dąbrowie Górniczej. 